\title{
Impact of Toxicants in Drinking Water Within Para-Mining Communities in Ghana
} \author{
Ablor $^{5}$ and Vandyck Mohammed ${ }^{6}$ \\ ${ }^{1}$ Department of Pharmacology, Kwame Nkrumah University of Science and Technology, Ghana \\ ${ }^{2}$ Department of Applied Chemistry and Biochemistry, University for Development Studies, Ghana \\ ${ }^{3}$ Department of Chemical Engineering, Durban University of Technology, South Africa \\ ${ }^{4}$ Department of Mechanical Engineering, University of Leeds, Leeds, United Kingdom \\ ${ }^{5}$ Department of Chemistry, University of Cape Coast, Cape coast, Ghana \\ ${ }^{6}$ Department of Minerals, University of Mines and Technology, Ghana
}

Bright Boafo Boamah ${ }^{1 *}$, Bright Vincent Annam², Edward Kwaku Armah ${ }^{3}$, Gifty Oppong Boakye ${ }^{4}$, Alexander

Submission: August 07, 2018; Published: September 21, 2018

*Corresponding author: Bright Boafo Boamah, Department of Pharmacology, Kwame Nkrumah University of Science and Technology, Kumasi, Ghana; Tel: +233546721229; Email: briteboafo@gmail.com

\begin{abstract}
Water contamination exists in various forms with toxicants either deep within the water bed or within the external environment. The degree of toxicity depends on the level of exposure which depends on the quantity of contaminants, their half-lives, reactiveness and its degree of accumulation. This study aimed at assessing the physicochemical properties of domestic water such as $\mathrm{pH}$, electrical conductivity, turbidity, total dissolved solids and total suspended solids. The ions determined were potassium, sodium, calcium, chloride and fluoride. Among the numerous heavy metals in extant within the environment, arsenic, cadmium, lead, copper, zinc, iron and aluminium were also assessed. The water samples were collected from twenty (20) dug-out wells from nine (9) communities which were in proximity to a mining site. A CETAC ASX-520 autosampler was used for the sample introduction. The physicochemical properties were assessed with Hanna Benchtop pH/EC/TDS meter. Ions were measured using the Hach Lange Spectrometer. The heavy metals were analyzed using the thermo Scientific iCAP 7400 ICP-OES Duo. The measured samples were compared with the World Health Organization set guidelines. All the physicochemical properties exhibited derangements within some samples except for total dissolved solids. The results of the arsenic, cadmium, copper, zinc contaminants were found below the WHO acceptable limits while lead, iron and aluminium had some samples with levels above the acceptable limits. All the ions measured were within acceptable limits. Although, most heavy metals were within acceptable limits, however, bio-accumulation from long term exposure can lead to toxicity.
\end{abstract}

Keywords: Toxicants; Heavy metals; Ions; Physicochemical properties

\section{Introduction}

Water is an essential component of life which cannot be understated. The biochemical reactions of humans and other living organisms in the environment depend on water for its efficiency [1]. Unfortunately, we find ourselves in a world where toxicants are gradually being introduced into our ecosystem, but our human body can barely be protected [2]. The World Health Organization (WHO) has various targets in making water accessible to all, especially those in third world countries [3]. The quantity of water supply to these vicinities are encouraging but the quality of water supply has always been questionable. The water supply to communities are currently derived from the surface or underground water [4]. The former was previously used until pollution of surface water-bodies by natural geologic and anthropogenic activities made them not suitable for human consumption. Unfortunately, underground water is gradually contaminated with other toxicants such as heavy metals [5]. These heavy metals cannot be eliminated from the ecosystem and hence allowable levels have been determined by the WHO in trying to keep the toxicants below the threshold at which these chemicals become toxic [6].

Macroscopic contaminants are easily removed through filtration techniques but microscopic contaminants such as heavy metals and coliforms are barely catered for in such situations [7]. Water bodies have been contaminated by various pollutants ranging from electrolytes, coliforms and heavy metals. Heavy metals are very common among communities in propinquity to mining and other industrial sites [8]. The seepage of toxins from mining fields into the soil and water-bodies are significant 
but rarely considered owing to poor regulatory bodies existing in Ghana $[9,10]$. The proximity of the mining sites to waterbodies is the main factor affecting exposure when the degree of exposure, number of toxicants and duration of exposure are kept constant [11]. Human factors such as age, obesity and presence of comorbidities such as renal or hepatic impairment greatly influence the degree of toxicity since these organs are involved in physiological clearance $[12,13]$. In an ecosystem with exposure to these toxins above safety levels, flora and fauna are not comestible and locality not suitable for human settlements $[14,15]$. Indirect intoxication from consumption of agricultural products such as fish, meat, vegetables and fruits in heavy metal-laden environments is one common means of intoxication $[16,17]$. Airborne transmission is the least considered pathway in intoxication by heavy metals in as much as a current study found no significant correlation between inhalational heavy metal dust and carcinogenicity [18], however, further studies will be required to investigate this area.

Heavy metals are metals with high atomic mass of or density about water which are poisonous to cellular functions in varying degrees [19]. There are at least 35 heavy metals known within the environment with specific physical, chemical and toxicological properties. The major heavy metals with inauspicious environmental influence include mercury $(\mathrm{Hg})$, lead $(\mathrm{Pb})$, arsenic (As), cadmium (Cd), zinc ( $\mathrm{Zn})$, manganese $(\mathrm{Mn})$ together with other noticeable toxicants $[9,20-22]$. These heavy metals build up in cells and affect molecular biochemical reactions through methylation, oxidative stress, ionic replacement mechanism, binding to metalloproteins and cell membrane destruction $[23,24]$. Bacteria can either halt the effects of the heavy metals by bio-transforming them into less active forms or activating them into very active metabolites. Eubacteria and archaea can induce the former reactions while prokaryotes augment production of the latter [25-28]. An aggravated toxicity can occur in humans if water is contaminated by the prokaryotes which speed up the conversion of most heavy metals to their active form, a classical example is methylation of arsenic into mono methyl arsenic acid (MMA) or dimethyl arsenic acid (DMA). The pH, conductance, dissolved solids and electrolytes are essential for maintaining normal human physiology [29]. Electrolytes such as sodium, potassium, chloride, fluoride are tightly controlled parameters in the human body owing to its importance in mechanisms such as nerve transmission, hormonal secretion and maintaining plasma homeostasis [30-32].

In Ghana, myriad of legal and uncontrolled mining activities has resulted in increased levels of these toxicants in the human ecosystem [33]. Surface water bodies have been destroyed through these activities which have rendered them unhealthy for human intake.

The impact of such heavy metals is additive in nature and compromise the biochemical systems upon chronic and repetitive exposure [32]. These heavy metals are extant in natural environment but in miniature quantities no significant adverse effects on the human body. The latter assertion has been highly debated upon owing to the cumulative toxicity of these metals in the human body $[34,35]$.

Human exposure to toxins results in multiple organ damage such as neurotoxicity, cardiotoxicity, nephrotoxicity, hepatotoxicity and haematotoxicity [36]. Genotoxicity is currently the concern of various environmental toxicologists who advocate for adequate control of these toxicant [37]. Genetic aberrations and mutations are the basis of carcinogenesis and teratogenicity $[38,39]$. Currently, the traditional etiologies and risk factors for most diagnosed diseases are absent in most clinically diagnosed conditions. Could there be an influence of such environmental toxicants modifying the traditional pathophysiology of diseases? Unfortunately, toxicological analysis is not part of routine tests done in Ghana and most third world countries stricken with environmental toxicants such as heavy metals. Toxicological analysis of various water-bodies prior to consumption is rarely done except for when packaged for commercial use.

This study was aimed at quantifying the physicochemical parameters in water from boreholes. Heavy metals in drinking water have adverse effects in the human body. Electrolytes, $\mathrm{pH}$, total suspended solids, conductance among other less common analytes were also considered.

\section{Materials and Methods}

\section{Selection and collection of samples}

The study was conducted on newly dug-out boreholes within 9 specific communities in the Western Region of Ghana. A total number of 20 newly dug-out boreholes were analyzed. The locations were selected based on their population and increased proximity to mining sites. These localities used water from rivers and because of intoxication with suspected effluents from mining sites, boreholes were dug up to replace their source of drinking water. Twenty samples of $100 \mathrm{ml}$ of each were collected and used for the physicochemical, heavy metals and electrolytes analyses. The samples were collected in de-ionized polyethylene bottles and kept in containing flask to eliminate contamination. Great care was taken during the period of sample transfer to eliminate contamination. The laboratory was well situated from the communities and the analysis of samples were done within 1 hour of collection. On-site analysis was done for 3 parameters ( $\mathrm{pH}$, turbidity and conductivity).

\section{Experimental analysis and instrumentation}

A thermo Scientific iCAP 7400 ICP-OES Duo was used for the metal analysis. This included arsenic, lead, copper, zinc, cadmium, iron, mercury and chromium. It uses a peristaltic pump for its sample introduction. A Duo view was set for the plasma view which allows automatic alternating of the plasma view. Elements expected at trace levels were analyzed axially, for best sensitivity and elements at high concentrations were measured radially, for best dynamic range. The anions were analyzed using the Hach Lange Spectrometer while the physical 
properties properties were analyzed using Hanna Benchtop pH/EC/TDS meter. A CETAC ASX-520 autosampler was used for the sample introduction to eliminate any human interferences which may lead to sample contamination.

Multi-element standards which contained 32 elements were prepared at various concentrations at $1 \mathrm{ppm}, 10 \mathrm{ppm}$ and $50 \mathrm{ppm}$. These standards were used for calibrating the instrument. A loaded blank (2ppm Zinc) was used as a Quality control check.

$5 \mathrm{ml}$ of the sample was transferred into the sample vials using pipette and arranged on the autosampler rack. The peristaltic pump drew samples into the pump tubing. The 0.45 -micron Glass concentric nebulizer aspirates the sample in the spray chamber. The sample then undergoes vaporization, atomization, ionization and excitation. The light emitted by each element was detected by a Charged Injection Device (CID). The signal was then digitized and then counts displayed on the user interface.

\section{Inferential analysis}

An inferential analysis was done using Graph Pad Prism software version 6. A paired t-test was done to assess the differences between the measured parameters and the World Health Organization's acceptable limit. A statistically significance level was set with a p-value of 0.05 with a $95 \%$ confidence limit.

\begin{tabular}{|c|c|c|c|c|c|}
\hline Parameters & pH & Turbidity & Electrical Conductivity & Total Suspended Solids & Total Dissolved Solids \\
\hline Sample 1 & 7.2 & 6.5 & 448 & 18 & 225 \\
\hline Sample 2 & 6.8 & 5 & 243.8 & 37 & 121.9 \\
\hline Sample 3 & 6.7 & 59.6 & 279.1 & 48 & 140 \\
\hline Sample 4 & 6.9 & 7.63 & 447 & 5 & 224 \\
\hline Sample 5 & 6.9 & 1.02 & 368 & 2 & 184 \\
\hline Sample 6 & 6.6 & 20.21 & 465 & 18 & 223 \\
\hline Sample 7 & 4.7 & 0 & 58.8 & 0 & 29.31 \\
\hline Sample 8 & 6.9 & 8.62 & 381 & 13 & 191 \\
\hline Sample 9 & 6.9 & 0.31 & 123.1 & 0 & 0 \\
\hline Sample 10 & 7 & 6.02 & 647 & 5 & 321 \\
\hline Sample 11 & 6.2 & 7.94 & 103.8 & 17 & 52.1 \\
\hline Sample 12 & 6.5 & 4.91 & 327 & 12 & 164 \\
\hline Sample 13 & 6.3 & 10.8 & 240.5 & 15 & 120.3 \\
\hline Sample 14 & 6.7 & 117 & 485 & 43 & 242 \\
\hline Sample 15 & 6.7 & 0 & 291.2 & 1 & 145.7 \\
\hline Sample 16 & 6 & 155 & 267.7 & 116 & 133.7 \\
\hline Sample 17 & 6 & 19.5 & 333 & 42 & 167 \\
\hline Sample 18 & 6.2 & 88.6 & 317 & 48 & 158 \\
\hline Sample 19 & 7 & 0.4 & 271.4 & 0 & 135.3 \\
\hline Sample 20 & 7.4 & 3.7 & 401 & 38 & 201 \\
\hline WHO Accepted Level & $6.50-8.50$ & 5 & 400 & $\leq 30.00$ & 500 \\
\hline
\end{tabular}

\section{Results and Discussion}

pH

A change in the body's $\mathrm{pH}$ can be triggered by internal cellular biochemical reactions or from an introduction of exogenous source of hydrogen ions. Any aberration in the $\mathrm{pH}$ of drinking water serves as a potential means of altering the body's pH. The accepted level pH by WHO is 6.5-8.5 $[40,41]$. In this study, the $\mathrm{pH}$ of all samples was within the acceptable range for human consumption as described by WHO except for sample $7(\mathrm{pH}=4.7)$, samples 16 and $17(\mathrm{pH}=6.0)$ as well as samples 11 and 18 ( $\mathrm{pH}=6.2$ ). The range of $\mathrm{pH}$ for analysed water samples in this study was between 4.7 to 7.4 (Table 1). Toxicity from ingested acidic water has local effects through irritation of the mucous membranes within the gastrointestinal tracts and systemically by affecting metabolic processes [42]. Acidic water has the potential to be consumed and undetected for a long time compared to alkaline water which has a bitter taste [43]. Acidic $\mathrm{pH}$ of water in the presence of heavy metals render these metals highly reactive and dangerous for human consumption [44]. Enzymatic reactions are tightly regulated under optimal body $\mathrm{pH}$ (7.35-7.45), these reactions are halted while proteins for specific actions in the body are denatured [45]. In the body, buffer systems exist to mitigate any aberration in $\mathrm{pH}$, but chronic exposure depletes the buffer system and result in acidosis [42]. 


\section{Turbidity}

The results indicate about $60 \%$ of the samples analysed had turbidity above the permissible level of 5 nephelometric turbidity units (NTU) by WHO. The lowest turbidity recorded was 0 NTU for samples 7 and 15 while the highest was seen in sample 16 with 155 NTU. The high turbidity could be ascribed to the absence of filtration for the water samples prior to analysis. Turbidity has no direct impact on health but variable indirect influences through interactions with microbes, heavy metals and other ions [46]. Turbid water has the propensity to serve as vehicles for carrying micro-organisms and shielding them against disinfectants [44]. It also results in harmful by-products such as trihalomethanes by reacting with chlorine.

\section{Electrical conductivity}

Electrical conductivity has a strong correlation with other physicochemical parameters such as chloride ions, total dissolved solids, total suspended solids and $\mathrm{pH}$ [40]. Ideally, pure water should de devoid of significant ionic concentration and hence be a poor conductor of electricity. The electrical conductivity of 6 samples were above the prescribed value of
$400 \mu \mathrm{s} / \mathrm{cm}$ by WHO. The range was between 102.3 to $647 \mu \mathrm{s} /$ $\mathrm{cm}$ which clearly shows that most of the samples were ionized and hence highly conductive. The WHO limit was exceeded in 6 locations within this study. High conductivity leads to increased corrosive nature of water which eventually leads to enhanced reactivity in the presence of heavy metals [45].

\section{Total dissolved solids}

Total dissolved solids (TDS) have a close association with electrical conductivity. The acceptable maximum level of total dissolved solids is $500 \mathrm{mg} / \mathrm{L}$. In this study, the range TDS was $0-242 \mathrm{mg} / \mathrm{L}$ as shown in Table 1 . The total dissolved solids in natural water largely comprised of $\mathrm{Na}^{+}, \mathrm{K}^{+}, \mathrm{Ca}^{2+}, \mathrm{Mg}^{2+}, \mathrm{Cl}^{-}, \mathrm{SO}_{4}{ }^{2-}$, $\mathrm{PO}_{4}^{3-}, \mathrm{H}_{4} \mathrm{SiO}_{4}^{2-}$, and $\mathrm{HCO}^{3-}$ [46].

\section{Total suspended solids}

With regards to the total suspended solids (TSS), it denoted variable degrees of contamination as the values ranged from 0 to $116 \mathrm{mg} / \mathrm{L}$. The measured TSS values were within WHO acceptable limits of $\leq 30 \mathrm{mg} / \mathrm{L}$, except for samples 2,3,14,16,17,18 and 20 . This showed a potential for these water sources to cause health problems [47] (Table 2).

Table 2: Differences in Quantity of Heavy Metals in Water Samples Compared with WHO Acceptable Limits.

\begin{tabular}{|c|c|c|c|c|c|c|c|}
\hline Parameters & Arsenic & Cadmium & Copper & Zinc & Iron & Lead & Aluminium \\
\hline Sample 1 & 1.42 & 0.7 & 6.4 & 6.4 & 383.5 & 20.4 & 25.3 \\
\hline Sample 2 & 1.42 & 0.2 & 0.02 & 2.6 & 136.1 & 7.5 & 65.2 \\
\hline Sample 3 & 1.12 & 0.6 & 61.3 & 3.7 & 1721 & 23.2 & 22.4 \\
\hline Sample 4 & 1.01 & 0 & 2.2 & 0 & 629.2 & 13.1 & 3.7 \\
\hline Sample 5 & 1.11 & 0.3 & 4.8 & 0.01 & 11.1 & 0.1 & 342.1 \\
\hline Sample 6 & 0.8 & 0.3 & 2.8 & 13.7 & 1643 & 5.9 & 0.01 \\
\hline Sample 7 & 0 & 0.4 & 46.4 & 41.9 & 55 & 5.4 & 0 \\
\hline Sample 8 & 2.9 & 0 & 0.8 & 0 & 570 & 1.1 & 0 \\
\hline Sample 9 & 0 & 0 & 1.7 & 0 & 269.2 & 3.6 & 0 \\
\hline Sample 10 & 0 & 0.1 & 3.5 & 0 & 528 & 5.4 & 2168 \\
\hline Sample 11 & 0 & 0.1 & 70 & 40 & 1820 & 0 & 0.1 \\
\hline Sample 12 & 1.9 & 0.2 & 0 & 0 & 1201 & 14.1 & 24 \\
\hline Sample 13 & 8.7 & 0.2 & 0 & 0 & 991.3 & 3.1 & 172 \\
\hline Sample 14 & 0 & 0.1 & 1 & 0 & 4838 & 6.8 & 329.9 \\
\hline Sample 15 & 3.9 & 0 & 1.7 & 0 & 2.7 & 14.3 & 0 \\
\hline Sample 16 & 1.5 & 2.9 & 6.7 & 20.7 & 9414 & 15 & 5091 \\
\hline Sample 17 & 1.7 & 1.1 & 9.2 & 3 & 1996 & 15 & 5 \\
\hline Sample 18 & 0.2 & 0.1 & 7 & 12 & 1288 & 22 & 56.9 \\
\hline Sample 19 & 0.45 & 0 & 3.7 & 0 & 78.5 & 1.7 & 20.7 \\
\hline Sample 20 & 0 & 0.1 & 2.6 & 0 & 38.7 & 7.4 & 95.6 \\
\hline WHO Accepted Levels & 10 & 3 & 1300 & 3000 & 300 & 10 & 200 \\
\hline
\end{tabular}

\section{Arsenic}

Ingestion of water is currently the main route of arsenic exposure. It could exist in variable forms such as inorganic arsenite and arsenate which occur in trivalent and pentavalent forms respectively [48]. The multiple chemical and oxidative states pose variable health risks to individuals who become exposed. In this study, all the samples had arsenic levels below the acceptable limit $(10 \mu \mathrm{g} / \mathrm{L})$ by WHO. Samples $7,9,10,11,14$ 
and 20 recorded no amount of arsenic during the time of collection. In the toxicokinetic of arsenic, absorption through the gastrointestinal tract is the greatest followed by the respiratory tract and then insignificantly through skin. At low doses, the degree of accumulation and duration of exposure are the main external factors which determine its chronic toxicity [49]. Acute toxicity occurs at high doses in the presence of a favorable pathway, thus gastrointestinal tract. In this study, if no intervention is put in place, chronic toxicity with or without carcinogenesis will be most likely untoward health impact owing to the low and sustained doses of arsenic. Inorganic and organic arsenical forms have the same toxicodynamic half-life but variable toxicokinetic [50]. The latter is eliminated easily from the human body which renders it less toxic compared to the former.

\section{Cadmium}

Cadmium is non-biodegradable in both man and in the environment, which makes bio-accumulation an important factor in its toxicity. Although, water serves a source of exposure only $5 \%$ to $15 \%$ of ingested cadmium is absorbed while inhalation is the major route of exposure, $10 \%$ to $50 \%$ depending on its size and solubility [51]. In this study, samples 16 and 17 had values of $2.9 \mu \mathrm{g} / \mathrm{L}$ and $1.1 \mu \mathrm{g} / \mathrm{L}$ respectively. Cadmium has a unique nature of accumulation throughout the life of the exposed individual which eventually leads to liver, pulmonary and renal toxicity [52]. The kidney is one of the first organs to be affected and could be one of the possible explanations for the high incidence of chronic renal disease even in the absence of known risk factors and etiologies currently in Ghana.

\section{Copper}

Copper exists in variable forms, it is less toxic in its metallic state but poisonous in the salt form [53]. Copper is one of the micro-nutrients required by the body in minute quantities which supports neuronal activities, absorption of elemental iron as well as serving as a co-factor for several redox enzymatic processes. Toxicity is minimal compared to other metals not utilized by the body physiologically [54]. The level of copper from the sources of drinking water were all below the WHO required limit of $1300 \mu \mathrm{g} / \mathrm{L}$. The highest level of copper recorded was $70 \mu \mathrm{g} / \mathrm{L}$ which can readily be bound to plasma ceruloplasmin and prevent tissue binding [55], but this level becomes significant in the presence of a pre-existing copper overload conditions such as Menkes syndrome and Wilson's disease [56].

\section{Zinc}

The quantity of zinc measured from the various water sources were within the acceptable limits as prescribed by the WHO $(3000 \mu \mathrm{g} / \mathrm{L})$. The range of zinc levels in this study was 0 to $41.9 \mu \mathrm{g} / \mathrm{L}$. However, zinc is an essential micro-nutrient required as a co-factor for several biochemical and enzymatic reactions in the body [54]. Zinc is readily metabolized and eliminated from the body and the impact of accumulation at minimal levels is not an issue compared to metals like cadmium.

\section{Iron}

The range of iron in analyzed water samples was between 2.7 to $9414 \mu \mathrm{g} / \mathrm{L}$. WHO places the acceptable limit of iron in drinking water at $300 \mu \mathrm{g} / \mathrm{L}$. Only 7 samples had their iron content within range while the highest recorded value was about 30 -fold the acceptable limit. The estimated daily requirement of iron is 10$50 \mathrm{mg}$ in the healthy human based on sex, age and physiological state $[57,58]$. However, the oral intake of water containing $300 \mu \mathrm{g} / \mathrm{L}$ of iron is equivalent to $0.6 \mathrm{mg}$ of iron, which puts the maximum amount of iron found within this study in sample 16 with $9414 \mu \mathrm{g} / \mathrm{L}$ at $18.8 \mathrm{mg}$ of iron. The minimum oral exposure required for acute toxicity is $600 \mathrm{mg}$, but caution should however be taken since iron can accumulate in tissues over a long time of exposure [59]. The toxicity of iron is dependent on the extent of its absorption as well as the amount of iron within the body [60]. Toxicity is at its peak when iron is given intravenously or intramuscularly [61].

\section{Lead}

Ideally, the human body should be devoid of lead exposure as variable toxicities occur even at exceedingly low levels owing to high accumulation rates [62]. The WHO, although, prescribing an acceptable level of $10 \mu \mathrm{g} / \mathrm{L}$ had 8 analyzed samples with level of lead above this set point ranging from 13.1 to $23.2 \mu \mathrm{g} / \mathrm{L}$. Independent factors affecting lead toxicity are age, sex, physiological state, dose and duration of exposure [63]. This is due to the differences in toxicokinetic, children absorb about 40 to $50 \%$ of ingested lead as compared to 3 to $10 \%$ in adults [64]. In plasma, after an average period of 4 to 6 weeks, lead is distributed into tissues such as liver, lungs, kidneys and brain [65]. The skeleton is the stable site of deposition where the halflife of lead is 10 to 35 years as compared to 30 to 30 days in plasma [66].

\section{Aluminium}

In this study, the analyzed aluminium level was ranged between 0 to $5190 \mu \mathrm{g} / \mathrm{L}$ with the WHO accepted level of $200 \mu \mathrm{g} / \mathrm{L}$. Aluminium concentration of more than $200 \mu \mathrm{g} / \mathrm{L}$ is not safe for consumption but can be used safely for other domestic activities such as bathing [67]. Erstwhile, groundwater was not a likely source of aluminium, but recent studies have also found high levels of aluminium in groundwater $[68,46]$. Aluminium toxicity ranges from mild effects like gastrointestinal disturbances to severe forms like hepatic, renal and recently implicated in Alzheimer's disease [69] (Table 3).

\section{Potassium}

Potassium levels in the analyzed water ranged from 0.05 to $12.83 \mathrm{mg} / \mathrm{L}$. Potassium currently has no laid down acceptable limit by the World Health Organization and the Environmental Protection Agencies [70]. Potassium is usually not found in natural drinking water although high amounts most likely due to addition of potassium permanganate (KMn04) as an oxidant in drinking water [71], which was not used in these analyzed 
samples. The maximum acceptable limit for KMn04 in treated water is 8 to $10 \mathrm{mg} / \mathrm{L}$ which implies that the levels of potassium found in this study are within safe limits. However, insignificant these values maybe, care should be taken in people with chronic renal impairment and neonates who have an incompetent kidney in handling potassium.

Table 3: Differences in Electrolytes Levels in Water Samples Compared with WHO Acceptable Limits.

\begin{tabular}{|c|c|c|c|c|c|}
\hline Parameters & Potassium & Sodium & Fluoride & Chloride & Calcium \\
\hline Sample 1 & 0.29 & 0.25 & 0.35 & 0.3 & 62.42 \\
\hline Sample 2 & 2.26 & 5.03 & 0 & 8 & 24.13 \\
\hline Sample 3 & 0.16 & 6.58 & 0.3 & 1 & 34.51 \\
\hline Sample 4 & 0.4 & 15.14 & 0 & 3.7 & 69.85 \\
\hline Sample 5 & 0.55 & 16.39 & 0 & 4.9 & 52.86 \\
\hline Sample 6 & 0.88 & 25.15 & 0 & 11.4 & 81.53 \\
\hline Sample 7 & 0.24 & 2.56 & 0 & 2.1 & 2.16 \\
\hline Sample 8 & 0.6 & 8.21 & 0.49 & 3.9 & 41.17 \\
\hline Sample 9 & 0.26 & 4.61 & 0 & 2.2 & 13.82 \\
\hline Sample 10 & 1.21 & 31.34 & 0 & 11.9 & 96.33 \\
\hline Sample 11 & 0.5 & 0.04 & 0.15 & 0.1 & 6.21 \\
\hline Sample 12 & 0.82 & 5.86 & 0 & 5.9 & 35.77 \\
\hline Sample 13 & 0.42 & 3.46 & 0 & 0 & 38.49 \\
\hline Sample 14 & 12.83 & 22.97 & 0 & 7.3 & 40.15 \\
\hline Sample 15 & 0.5 & 7.83 & 0 & 4.6 & 29.29 \\
\hline Sample 16 & 1.82 & 21.77 & 0 & 10.63 & 34.06 \\
\hline Sample 17 & 0.72 & 21.96 & 0.06 & 8.4 & 44.79 \\
\hline Sample 18 & 0.05 & 15.85 & 0 & 7.3 & 35.41 \\
\hline Sample 19 & 0.18 & 3.9 & 1.1 & 1.6 & 42.87 \\
\hline Sample 20 & 0.23 & 3.28 & 0.29 & 4 & 75.39 \\
\hline WHO Acceptable Levels & - & 250 & 1.5 & 200 & 75 \\
\hline
\end{tabular}

\section{Sodium}

In this study, the level of sodium was within the acceptable limit $(250 \mathrm{mg} / \mathrm{L})$ beyond which toxicities occur. The minimum value recorded was $0.05 \mathrm{mg} / \mathrm{L}$ with a maximum of $31.34 \mathrm{mg} / \mathrm{L}$. Hypernatremia usually presents with challenges, with the most implicated being hypertension. Sodium is quite ubiquitous and can be found mainly in food, hence low levels in sources of drinking water cannot create a problem of insufficiency.

\section{Fluoride}

Drinking water contains very low to absent fluoride content. Most underground drinking water contains about 0 to $60 \mathrm{mg} / \mathrm{L}$ of fluoride [72], although an acceptable limit of $1.50 \mathrm{mg} / \mathrm{L}$ has been prescribed by the WHO. This study had findings which ranged from 0 to $1.10 \mathrm{mg} / \mathrm{L}$ which were in conformity with the accepted guidelines.

\section{Chloride}

Chloride levels connote the degree of salinity as well as electrical conductivity of a water source. Ideally, underground water contains less amount of salt unless treated with chlorine [73-78]. It is the commonest anion found in drinking water which binds with various cations to form salts of calcium, sodium and magnesium [79]. The chloride levels recorded in this study, 0.00 to $11.90 \mathrm{mg} / \mathrm{L}$ were within safe limits and hence appropriate for drinking. Low and insignificant levels of chloride.

\section{Calcium}

Calcium currently stands as the most abundant mineral in the human body and its concentration of more than $200 \mathrm{mg} / \mathrm{L}$ in drinking water is rare. Its presence strongly correlates with the degree of hardness in water. In this study, the range of measured calcium in the sources of drinking water ranged from 2.16 to $96.33 \mathrm{mg} / \mathrm{L}$ with about $15 \%(\mathrm{n}=3)$ having levels beyond the WHO acceptable limit of $75 \mathrm{mg} / \mathrm{L}$.

\section{Conclusion}

This study highlighted the presence of heavy metals, electrolytes and other physicochemical parameters of newly dugout boreholes within some para-mining communities in Ghana. The findings suggested that the sources of water analyzed had most samples within the permissible range per the World Health Organization guidelines. The physicochemical parameters were variable and subject to distortion in the human homeostatic mechanisms. High levels in iron, lead and aluminium pose much danger to the exposed individuals owing to the toxicities which might emerge. Heavy metals present in water within acceptable 
limits such as arsenic, lead and cadmium are of great concern due to their uniqueness in accumulation in the human body over a long period of time. In such instances, near zero or zero levels are required for human consumption. Electrolytes were within acceptable levels safe for human consumption. Aberrations in the parameters warrant all water bodies both existing and new to be analyzed for the presence of contaminants around mining sites.

\section{References}

1. Yang X, Duan J, Wang L, Li W, Guan J, et al. (2015) Heavy metal pollution and health risk assessment in the Wei River in China. Environ Monit Assess 187(3): 111.

2. Ab Razak NH, Praveena SM, Aris AZ, Hashim Z (2015) Drinking water studies: A review on heavy metal, application of biomarker and health risk assessment (a special focus in Malaysia). J Epidemiol Glob Health 5(4): 297-310.

3. Rehman K, Fatima F, Waheed I, Akash MSH (2018) Prevalence of exposure of heavy metals and their impact on health consequences. J Cell Biochem 119(1): 157-184.

4. Ukpong EC, Okon BB (2013) Comparative Analysis of Public and Private Borehole Water Supply Sources in Uruan Local Government Area of Akwa Ibom State, International Journal of Applied Science and Technology 3(1): 1-16.

5. Valentin GG (2012) Comparative Analysis of Drinking Water Mineral Composition. Bulletin UASVM Agriculture 69(2).

6. Zhaoyong Z, Abuduwaili J, Fengqing J (2015) Heavy metal contamination, sources, and pollution assessment of surface water in the Tianshan Mountains of China. Environ Monit Assess 187(2): 33.

7. Ab Razak NH, Praveena SM, Aris AZ, Hashim Z (2016) Quality of Kelantan drinking water and knowledge, attitude and practice among the population of Pasir Mas, Malaysia. Public Health 131: 103-11.

8. Zhang L, Mo Z, Qin J, Li Q, Wei Y, et al. (2015) Change of water sources reduces health risks from heavy metals via ingestion of water, soil, and rice in a riverine area, South China. Sci Total Environ 530(531):163170.

9. Shanbehzadeh S, Marzieh VD, Akbar H, Toba K (2014) Heavy Metals in Water and Sediment: A Case Study of Tembi River 2014: p5.

10. Bempah CK, Ewusi A (2016) Heavy metals contamination and human health risk assessment around Obuasi gold mine in Ghana. Environ Monit Assess 188(5): 261.

11. Mahurpawar M (2008) Effects of Heavy Metals on Human Health. International Journal of Research p.1-7.

12. Andersen 0 (1999) Principles and Recent Developments in Chelation Treatment of Metal Intoxication. Chem Rev 99(9): 2683-2710.

13. Andersen O, Aaseth J (2002) Molecular mechanisms of in vivo metal chelation: implications for clinical treatment of metal intoxications. Environ Health Perspect 110(s5): 887-890.

14. Knasmüller S, Gottmann E, Steinkellner H, Fomin A, Pickl C (1998) Detection of genotoxic effects of heavy metal contaminated soils with plant bioassays. Mutat Res 420(1-3): 37-48.

15. Nagajyoti PC, Lee KD, Sreekanth TVM (2010) Heavy metals, occurrence and toxicity for plants: a review, Environmental Chemistry Letters 8(3): 199-216.

16. Tchounwou PB, Yedjou CG, Patlolla AK, Sutton DJ (2012). Heavy Metals Toxicity and the Environment. EXS 101: 133-64.

17. Darlington TK, Neigh AM, Spencer MT, Nguyen OT, Oldenburg SJ
(2009) Nanoparticle characteristics affecting environmental fate and transport through soil. Environ Toxicol Chem 28(6): 1191-1199.

18. Costa M (1997) Toxicity and Carcinogenicity of Cr (VI) in Animal Models and Humans. Crit Rev Toxicol 27(5): 431-442.

19. Thomas Mkude I (2015) Comparative Analysis of Heavy Metals from Groundwater Sources Situated in Keko and Kigogo Residential Areas, Dar es Salaam, Journal of Water Resources and Ocean Science 4(1): 1-5.

20. Abulude F, Obidiran G, Orungbemi S (2007) Determination of Physicochemical Parameter and Trace Metal Contents of Drinking Water Samples in Akure Nigeria.

21. Ray C, Jain R, Ray C (2011) Drinking Water Treatment TechnologyComparative Analysis.

22. Muhammad S, Shah MT, Khan S (2011) Health risk assessment of heavy metals and their source apportionment in drinking water of Kohistan region, northern Pakistan, Microchemical Journal.

23. Kannan GM, Tripathi N, Dube SN, Gupta M, Flora SJ (2001) Toxic Effects of Arsenic (III) on Some Hematopoietic and Central Nervous System Variables in Rats and Guinea Pigs. J Toxicol Clin Toxicol 39(7): 675-682.

24. Kalia K, Flora SJ (2005) Strategies for Safe and Effective Therapeutic Measures for Chronic Arsenic and Lead Poisoning. J Occup Health 47(1): 1-21.

25. Zhang X, Yang H, Cui Z (2017) Migration and speciation of heavy metal in salinized mine tailings affected by iron mining. Water Sci Technol 76(7-8): 1867-1874.

26. Mishra D, Flora S (2008) Differential oxidative stress and DNA damage in rat brain regions and blood following chronic arsenic exposure, Toxicol Ind Health 24(4): 247-256.

27. Kell DB (2010) Towards a unifying, systems biology understanding of large-scale cellular death and destruction caused by poorly liganded iron: Parkinson's, Huntington's, Alzheimer's, prions, bactericides, chemical toxicology and others as examples, Arch Toxicol 84(11): 825889.

28. Srebotnjak T (2010) Establishing Environmental Sustainability Thresholds and Indicators. Final report.

29. Shigut DA (2017) Assessment of physicochemical quality of borehole and spring water sources supplied to Robe Town, Oromia region, Ethiopia. Applied Water Science 7(1): 155-164.

30. Ikeme CH, Dioha IJ, Olasusi KA, Promise UC (2014) Physicochemical Analysis of Selected Borehole Water in Umuihi, Town Imo State, Nigeria, International Journal of Scientific \& Engineering Research 5(8): 680-689.

31. Adekola O, Bashir A, Kasimu AM (2015) Physicochemical characteristics of borehole water quality in Gassol Taraba State, Nigeria. 9(2): 143154.

32. Jan AT, Azam M, Siddiqui K, Ali A, Choi, et al. (2015) Heavy metals and human health: Mechanistic insight into toxicity and counter defense system of antioxidants. International Journal of Molecular Sciences 16(12): 29592-29630.

33. Inam E, Inoh GG, Nnanake Abasi OO, Bassey BE (2017) Physicochemical Characteristics and Health Risk Assessment of Drinking Water Sources in Okoroette Community, Eastern Coast of Nigeria. American Journal of Water Resources 5(1): 13-23.

34. Egga NS, Mafuyai ES (2014) Asian Review of Environmental and Earth Sciences Physico-Chemical and Microbial Assessment of some Well Water from Mista-Ali Town, Bassa LGA. Plateau State-Nigeria 1(2): 3942.

35. Ayodeji AS, Abubakar S, Samuel E (2017) Physicochemical Analysis of Underground Water in Zaria Metropolis, Kaduna State, Nigeria. American Journal of Chemical Engineering 5(6): 158-162. 
36. Singh AP, Goel RK, Kaur T (2011) Mechanisms pertaining to arsenic toxicity. Toxicol int 18(2): 87-93.

37. Rasool A (2016) Arsenic and heavy metal contaminations in the tube well water of Punjab, Pakistan and risk assessment: A case study. Ecological Engineering 95: 90-100.

38. Quievryn G, Peterson E, Messer J, Zhitkovich A (2003) Genotoxicity and Mutagenicity of Chromium (VI)/Ascorbate-Generated DNA Adducts in Human and Bacterial Cells. Biochemistry 42(4): 1062-1070.

39. Salnikow K, Donald SP, Bruick RK, Zhitkovich A, Phang JM, et al. (2004) Depletion of Intracellular Ascorbate by the Carcinogenic Metals Nickel and Cobalt Results in the Induction of Hypoxic Stress. J Biol Chem 279(39): 40337-40344

40. Nzubechukwu Edwin, Udu Ama Ibiam, Ikechukwu okorie Igwenyi, Victor Chibueze Ude, Solomon Nwanze Eko (2015) Evaluation of Physicochemical Properties, Mineral and Heavy Metal Content of Drinking Water Samples in Two Communities in South-East, Nigeria: A Public Health Implication. Journal of Environment and Earth Science $5(9)$.

41. Mary A Bisi Johnson, Kehinde O Adediran, Saheed A Akinola, Elizabeth O Popoola, Anthony I Okoh (2017) Comparative physicochemical and microbiological qualities of source and stored household waters in some selected communities in southwestern Nigeria. Sustainability (Switzerland).

42. Alemu T, Mulugeta E, Tadese M (2017) Determination of physicochemical parameters of Hora natural mineral water and soil in Senkele Kebele, Oromia Region, Ethiopia. Cogent Chemistry 153.

43. Mohsin M, Safdar S, Asghar F, Jamal F (2013) Assessment of Drinking Water Quality and its Impact on Residents Health in Bahawalpur City. International Journal of Humanities and Social Science 3(15): 114-128.

44. Kale VS (2007) Consequence of Temperature, pH, Turbidity and Dissolved Oxygen Water Quality Parameters, International Advanced Research Journal in Science, Engineering and Technology 3(8): 186190.

45. Rahmanian N, Siti Hajar Bt Ali, Homayoonfard M, Ali NJ, Rehan M, et al (2015) Analysis of physiochemical parameters to evaluate the drinking water quality in the state of perak, Malaysia. Journal of Chemistry 1-10.

46. Polasi LT, Nakin MDV, Magayiyana Z, Musampa CM (2017) Effects of location on the physico-chemical properties of water in the Matatiele Local Municipality. South Africa 210: 713-723.

47. Cohen SM, Arnold LL, Eldan M, Lewis AS, Beck BD (2006) Methylated arsenicals: The implications of metabolism and carcinogenicity studies in rodents to human risk assessment. Crit Rev Toxicol 36(2): 99-133.

48. Ebele B (2009) Mechanisms of arsenic toxicity and carcinogenesis. African Journal of Biochemistry Research 3(5): 232-237.

49. Hughes MF, Beck BD, Chen Y, Lewis AS, Thomas DJ (2011) Arsenic exposure and toxicology: A historical perspective. Toxicol Sci 123(2): 305-332.

50. Shuaibu UOA et al. (2014) Impact of Lead and Cadmium in Drinking Water. International Journal of Technical Research (6): 31-35.

51. Bernard A (2008) Cadmium \& its adverse effects on human health Indian J Med Res 128(4): 557-564.

52. Ashish B, Neeti K, Himanshu K (2013) Copper Toxicity: A Comprehensive Study. Research Journal of Recent Sciences 2: 58-67.

53. Palacio, Soraya Moreno (2005) Correlation between heavy metal ions (copper, zinc, lead) concentrations and root length of Allium cepa L. in polluted river water. Brazilian Archives of Biology and Technology 48: 191-196.

54. Ramos D, Mar D, Ishida M, Vargas R, Gaite M, et al. (2016) Mechanism of Copper Uptake from Blood Plasma Ceruloplasmin by Mammalian
Cells. PloS one. 11(3): e0149516.

55. Paola Di Vaio, Elisa Magli, Giuseppe Caliendo, Angela Corvino, Ferdinando Fiorino, et al. (2018) Heavy Metals Size Distribution in PM10 and Environmental-Sanitary Risk Analysis in Acerra (Italy). Atmosphere 9(2): 58.

56. Lim KH, Riddell LJ, Nowson CA, Booth AO, Szymlek Gay EA (2013) Iron and zinc nutrition in the economically-developed world: A review. Nutrients 5(8): 3184-3211.

57. Beck KL, Conlon CA, Kruger R, Coad J (2014) Dietary determinants of and possible solutions to iron deficiency for young women living in industrialized countries: A review. Nutrients 6(9): 3747-3776.

58. Kohgo Y, Ikuta K, Ohtake T, Torimoto Y, Kato J (2008) Body iron metabolism and pathophysiology of iron overload. Int J Hematol 88(1): 7-15.

59. Kazaure SZ, Isa HA, Mohammed Y, Namadi MM (2015) Comparative Analysis of Physicochemical Parameters and Heavy Metals of Public Water Supply in Kaduna Metropolis. IOSR Journal of Applied Chemistry 8(11): 21-26.

60. Albretsen J (2006) The toxicity of iron, an essential element. Veterinary Medicine Toxicology Brief pp: 82-90.

61. Brown MJ, Margolis S (2012) Lead in drinking water and human blood lead levels in the United States. Morbidity and mortality weekly report 61 Suppl: $1-9$

62. Al-Othman MA, Al-Othman ZA, El-Desoky GE, Aboul-Soud MAM, Habila MA, et al. (2013) Lead in drinking water and human blood in Riyadh City, Saudi Arabia. Arabian Journal of Geosciences 6(8): 3103-3109.

63. Dozier MC, Mcfarland ML (2013) Drinking Water Problems: Lead. The Texas A\&M University System pp: 2-04.

64. Dye BA, Hirsch R, Brody DJ (2002) The relationship between blood lead levels and periodontal bone loss in the United States, 1988-1994. Environmental Health Perspectives 110(10): 997-1002.

65. Rabinowitz MB (1991) Toxicokinetics of bone lead. Environ Health Perspect 91(5): 33-37.

66. Tomperi J, Pelo M, Leiviskä K (2013) Predicting the residual aluminum level in water treatment process. Drink Water Eng 6(1): 39-46.

67. Vesna Kostik, Biljana Manevska, Shaban Memeti, Biljana Gjorgeska, Sofija Petkovska (2014) Determination of Aluminium content in the Potable Water in the Republic of Macedonia from the Period 20112014. Journal of Hygienic Engineering and Design 62: 41-46.

68. Dzulfakar MA, Shaharuddin MS, Muhaimin AA, Syazwan AI (2011) Risk assessment of aluminum in drinking water between two residential areas. Water 3(3): 882-893.

69. Barbosa Lima R, Silva JHV da, Givisiez PEN, Martins TDD, Saraiva EP, et al. (2014) Influence of environmental temperature and electrolyte balance on the performance of quails (Coturnix Coturnix Coturnix). Brazilian Journal of Poultry Science 16(3): 249-256.

70. Sundem L (2014) Quality of drinking water in Afghanistan.

71. World Health Organization (1996) Sodium in Drinking-water Background document for development of WHO Guidelines for Drinking-water Quality. Guidelines for Drinking Water Quality.

72. Quality D (1996) Chlorine in Drinking-water Background document for development of WHO Guidelines for Drinking-water Quality.

73. Eshraga Abd EIMagid Basllir (2005) Assessment of the Quality of Drinking Water in Khartoum State.

74. Feldman PR, Rosenboom JW, Saray M, Navuth P, Samnang C, et al. (2007) Assessment of the chemical quality of drinking water in Cambodia. J water Health 5(1): 101-116. 
75. Napacho ZA, Manyele SV (2010) Quality assessment of drinking water in Temeke District (part II): Characterization of chemical parameters. African Journal of Environmental Science and Technology 4(1): 775 789.

76. Sorlini S, Palazzini D, Sieliechi JM, Martin BN (2013) Assessment of Physical-Chemical Drinking Water Quality in the Logone Valley (ChadCameroon). Sustainability 5(7): 3060-3076.

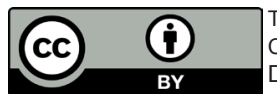

This work is licensed under Creative Commons Attribution 4.0 License

DOI: 10.19080/OAJT.2018.03.555620
77. Meride Y, Ayenew B (2016) Drinking water quality assessment and its effects on residents health in Wondo genet campus, Ethiopia. Environmental Systems Research 5(1).

78. Typical C (2010) Sodium and Chloride in Drinking Water. Pp: 3-5.

79. Morii H (2007) Magnesium and Calcium in Drinking Water. In Nishizawa Y, Morii H, Durlach J (Eds.), New Perspectives in Magnesium Research: Nutrition and Health. London: Springer, London, pp: 11-18.

\section{Your next submission with Juniper Publishers will reach you the below assets}

- Quality Editorial service

- Swift Peer Review

- Reprints availability

- E-prints Service

- Manuscript Podcast for convenient understanding

- Global attainment for your research

- Manuscript accessibility in different formats

( Pdf, E-pub, Full Text, Audio)

- Unceasing customer service

Track the below URL for one-step submission https://juniperpublishers.com/online-submission.php 